\title{
WORKPLACE CHARACTERISTICS AND EMPLOYMENT OF OLDER WORKERS
}

\author{
by
}

\author{
Chinhui Juhn * \\ University of Houston and NBER
}

and

\author{
Kristin McCue * \\ U.S. Bureau of the Census
}

CES 12-31 September, 2012

The research program of the Center for Economic Studies (CES) produces a wide range of economic analyses to improve the statistical programs of the U.S. Census Bureau. Many of these analyses take the form of CES research papers. The papers have not undergone the review accorded Census Bureau publications and no endorsement should be inferred. Any opinions and conclusions expressed herein are those of the author(s) and do not necessarily represent the views of the U.S. Census Bureau. All results have been reviewed to ensure that no confidential information is disclosed. Republication in whole or part must be cleared with the authors.

To obtain information about the series, see www.census.gov/ces or contact C.J. Krizan, Editor, Discussion Papers, U.S. Census Bureau, Center for Economic Studies 2K130F, 4600 Silver Hill Road, Washington, DC 20233, CES.Papers.List@census.gov. 


\begin{abstract}
As aging of the U.S. population places increased demands on public programs such as Social Security, an important question is how long older Americans are willing and able to work before they retire from the labor force. While studies based on household surveys have provided information on the role of savings, health status, pension and health insurance coverage, there is relatively little information on how workplace and employer characteristics affect the employment of older workers. In this study we use linked employer-employee data to explore the relationship between the characteristics of jobs held at age 55 and early retirement. We focus on a sample of 63-year-olds drawn from the 2005-2008 American Community Survey. We match this sample to information on their earnings, employment, employers and coworkers drawn from the Longitudinal Employer-Household Dynamics data for the years in which they age from 55 to 63. We use employment status as reported in the ACS to split the sample into those who have retired by age 63 and those who continue to work. We then examine differences between early retirees and continuing workers in the characteristics of their employment at age 55, and at how these characteristics change as they approach age 63. We find that early retirees are more likely to be employed by larger employers at age 55 than are continuers. They work for employers with somewhat higher pay than do continuers, and are less likely to have young coworkers.
\end{abstract}

*Any opinions and conclusions expressed herein are those of the authors and do not necessarily represent the views of the U.S. Census Bureau. All results have been reviewed to ensure that no confidential information is disclosed. This research was supported by a grant from the U.S. Social Security Administration (SSA) as part of the Retirement Research Consortium (RRC). The findings and conclusions are solely those of the authors and do not represent the views of SSA, any agency of the Federal Government, the NBER Retirement Research Center, CRR, or MRRC. We thank Olivia Mitchell for helpful comments. 


\section{Introduction}

The ability of older Americans to maintain gainful employment is of increasing importance as baby boom cohorts reach retirement age and pressures on public programs build. While the labor force participation rates of older Americans trended downward for most of the 20th century, this trend began to reverse in the 1990s, suggesting that older Americans may be both willing and able to work into their 60s and early 70s (Maestas and Zissimopoulos 2010, Munnell and Sass 2008). Researchers have explored both supply-side and demand-side explanations for the recent upward trend, including changes in the Social Security program itself, the shift from defined benefit to defined contribution pension plans, and the rise in the education level of the workforce. Examining the effects of Social Security reforms, Gustman and Steinmeier (2006) conclude that the removal of the retirement earnings test and the increases in the full retirement age from 65 to 67 played a relatively minor role in the recent rise in labor supply of older Americans. Likewise, Munnell and Sass (2008) argue that while changes in pension characteristics are likely to affect future retirees, they have not been an important factor for recently retired cohorts. Blau and Goodstein (2010) on the other hand find that a significant portion of the increase in employment can be explained by increasing education levels among older populations.

While studies based on household surveys have provided extensive information on the role of savings, health status, pension and health insurance coverage, there are fewer papers examining how workplace and employer characteristics affect the employment of older workers. In this paper, we explore the importance of these variables using matched employer-employee data. How might employer and workplace characteristics affect retirement decisions of older workers? One important variable may be industry or sector of employment. Blue collar jobs in construction and manufacturing may require physically demanding work leading to earlier retirement. Over time, the shift from manufacturing to service sector jobs may have both increased labor supply of older workers as well as increased the demand for older workers by reducing the importance of physically demanding work. Recent papers have also shown that skill requirements have changed even within sectors, with technology reducing the demand for routine physical tasks in favor of non-routine cognitive tasks (Autor, Levy, and Murnane 2003). Changes in technology could either help or hinder employment of older workers. On one hand, technology change may shift demand away from physically demanding work in blue-collar jobs, benefiting older workers as in the argument above. On the other hand, technology change may require investment in new skills and the shorter horizons of older workers may make it less likely that they invest to adapt to these changes (Bartel and Sicherman 1993, Ahituv and Zeira 2011). 
Another workplace characteristic that could affect employment of older workers are coworker characteristics and behavior. Recent papers have found substantial peer effects in retirement with individuals significantly more likely to retire when co-workers retire (Brown and Laschever 2010, Chalmers and Johnson 2008). Potential sources of peer effects on retirement are the existence of age norms or inference of optimal retirement age based on behavior of peers. Co-workers could also matter because workers care about their relative standing in the workplace. A recent paper by Card, Mas, Moretti, and Saez (2011) finds that workers who find out they are paid below the median wage in the firm report lower job satisfaction and are more likely to search for a new job. In this paper we use linked employeremployee data to study the importance of employer and co-worker characteristics for the employment of older men and women. In particular, we focus on a better understanding of the determinants of early retirement behavior (retirement at age 62 versus at a later age).

\section{Data}

Our empirical work combines information from two Census data sources: the American Community Survey (ACS) and the Longitudinal Employer-Household Dynamics(LEHD) database. The ACS is an on-going survey that collects data from about 2 million households per year 1 The LEHD database draws much of its data from complete sets of unemployment insurance (UI) earnings records for a subset of U.S. states. All 50 states and the District of Columbia have been in the LED partnership since December, 2010. However, the version of the data we are currently using includes 43 states with data for 2000-2008, and a somewhat smaller number for earlier years. Workers' earnings records have been matched to characteristics of their employer gathered in quarterly administrative UI reports and through Census Bureau business censuses and surveys.2 Basic demographic data are also available for workers.

The LEHD data have the important advantage of allowing us to measure employer and workforce characteristics using information on all employees of all UI-covered employers in the included states. Thus, we can identify basic characteristics of all coworkers. We also match in information on retirement plans using data from Form 5500 filings. In a future draft we intend to use information on firm size and age from the Longitudinal Business Database (LBD) as well. The LBD is a longitudinally linked version of Census's Business Register, the

\footnotetext{
${ }^{1}$ The ACS has had a nationally representative sample since 2000, but sample sizes were smaller prior to 2005.

${ }^{2} \mathrm{~A}$ full description of the LEHD data infrastructure can be found at Abowd, Vilhuber, McKinney, Sandusky, Stephens, Andersson, Roemer, and Woodcock (2006).
} 
list of all private sector employers that the Census Bureau maintains as a sampling frame for business surveys.

We construct our data set around older adults who have earnings in the LEHD database during the years 1996-2008 and who respond to the ACS during 2005-2008. The core sample for our analysis are men and women who have LEHD earnings in the year they turn 55 and report their employment status in the ACS around the age of 63 . This gives us a sample for which we can track earnings and employment as they age from 55 to 63. Given currently available data, this group is drawn from 1942-1946 birth cohorts. We then further restrict our sample by including only individuals who have at least three quarters of earnings during the year that they are age 55. We impose this requirement to focus on those working in covered states and jobs so that we can, with reasonable accuracy, interpret periods without observed earnings as periods without employment.

The ACS provides information on workers' education, occupation, sources of income, marital status, and spousal characteristics. The ACS also asks individuals their employment status last week, whether they were employed at all over the last twelve months, and whether they are seeking work if not currently employed. We use this ACS information on employment status to construct an indicator of early retirement, and then use LEHD employment histories to check consistency.

We use the LEHD data for 1996-2008 to both obtain longitudinal information on own earnings and employment histories for our core sample, and to construct similar measures for the earnings and employment histories of their coworkers. The LEHD data also allow us to look at basic demographics of coworkers, including coworker age which will be useful in identifying peers. They also provide information on establishment employment, payroll, and industry. We can link LEHD data to the LBD to obtain additional information on firm size and age. We have not exploited these measures in this draft, but will do so in the next.

While we do not have age-55 survey reports of employment for our primary sample, we can use younger cohorts to illustrate the effects of conditioning our sample on UI-covered employment in LEHD-covered states at age 55. To do this, we take a separate sample of employed 55 year olds from the 2005-2008 ACS samples and examine how the characteristics of those who match to LEHD earnings differ from the characteristics of those who do not. We use a sample of 55 year-old respondents who report working in the previous 12 months, and identify the subset with LEHD earnings in at least one of the four quarters that end with the quarter containing their ACS interview.

In Table 1 we present information on the share with matched earnings and likely reasons for those who are not matched. The table shows that 67 percent of working men in this ACS 
sample match to LEHD earnings records. The match rate is somewhat higher (71 percent) for women. There are several reasons for non-matches, including lack of adequate information (7 percent). Federal employees and ex-military members are covered by separate Federal UI programs and data from these programs are not currently included in the LEHD extract we are using. Those reporting federal employment and not matching account for about 3 percent of this sample. Unincorporated self-employed workers are also not covered by UI, and 7 percent of this sample report that they are unincorporated self-employed and are not matched. Not all states are in the LEHD data we use, and those who do not match and are employed in non-LEHD states account for another 7 percent. Finally, certain types of jobs and workers have lower coverage rates, including employees of small agricultural employers, student employees, insurance and real estate agents who work on commission, and employees of non-profit organizations. UI is estimated to cover over 96 percent of private wage and salary jobs ${ }^{3}$ so while we would expect some non-matches even for those working in LEHD states, we would expect considerably less than the observed 9 percent of sample members. Some of the excess non-matches are likely to reflect misreporting of type of employment - for example, people paid as contract workers but reporting wage and salary employment.4

Table 2 gives some evidence on how conditioning on an age-55 match affects the characteristics of our sample. Our matched sample is slightly better educated and in the case of men, also appears to have higher total income. The education difference is due to relatively low match rates among those who did not graduate from high school. For men, this group is somewhat more likely than more educated workers to work in sectors with lower match rates such as agriculture and construction. For women, the differences between the matched and non-matched populations are small.

\subsection{Defining early retirement}

We use ACS information rather than LEHD measures to define retirement for several reasons. The first is the reason mentioned earlier: the ACS has self-reported measures of labor market status distinguishing being out of the labor force and being unemployed. The second reason is that due to non-coverage issues in the LEHD, it is difficult as a practical matter to distinguish between retirement and employment in non-covered jobs. For example, an individual who has zero matched earnings in any given quarter may be retired or he/she may be working in a non-covered job (e.g. federal employment, realtors) or working in states not included

\footnotetext{
${ }^{3}$ See Bureau of Labor Statistics (1997).

${ }^{4}$ Abraham, Haltiwanger, Sandusky, and Spletzer (2009) provide more detailed discussion of sources of differences between employment measured in administrative records and that measured in survey data.
} 
in the LEHD data. We define as retired those who are interviewed by the ACS when they are around 63 years old and report either being out of the labor force at the survey date or long-term unemployed (unemployed at the survey date and did not work for at least one year) 5

Figure 1 examines quarterly LEHD earnings leading up to and following the ACS interview. About 60 percent of our sample is employed at the time of their ACS response, and that group continues to have high rates of employment in the following quarters. It is interesting to note that among those who report not being in the labor force at the time of the interview but having worked sometime in the last 12 months, about 30 percent continued to have positive earnings two quarters after the interview. The figure highlights the fact that retirement is not always a discrete transition but for some is a gradual process that could span several years. The figure also illustrates that there are two types of early retireesthose who gradually leave the labor force (the 30 percent of our sample who are currently not working and did not work in the last 12 months) and another group that leaves somewhat more abruptly (the roughly 10 percent of our sample who are currently out of the labor force but worked in the last 12 months). Although the currently unemployed who worked in the last 12 months do not appear to be all that different from those who are currently out of the labor force, we have taken a conservative approach and counted them as not retired. That group is much smaller than the others and so exluding them from retirees has little effect on our results.

\subsection{Differences between retirees and continuers at age 63}

Table 3 compares characteristics from the ACS for those we classify as remaining in the labor force ("continuers") and those we classify as retired at roughly age 62 . The table shows that early retirees are less educated than those who continue to work past age 62 . Among men, roughly 11 percent of continuers have less than a high school diploma while over 15 percent of the early retirees fall into this least educated category. Conversely, roughly 39 percent of male continuers are college graduates compared to 28 percent of the early retirees. These patterns by education also exist for women but are less pronounced. Marital status, on the other hand, has the opposite relationship to retirement for men and women. Among men, early retirees are less likely to be married and living with a spouse. Among women, the opposite is true with retirees more likely to be married. This is likely due to the fact

\footnotetext{
${ }^{5}$ More precisely, we use those who are between 62.5 and 63.5 years old at the time of the survey, so that the 12-month reference period for employment and income includes at least six months in which they were 62 .
} 
that wives tend to be younger than their husbands and there are strong complementarities in non-working time among older couples (Juhn and Potter 2008). Women in this age range are likely to have husbands who have already reached the full retirement age. Not surprisingly Social Security and retirement income account for 68 percent of total income among early retirees while they account for approximately 10 percent of income among the continuers. For those still working at age 62, wage and salary earnings account for over 80 percent of income for both men and women.

\subsection{Earnings and employment dynamics between ages 55 and 63}

In this section we compare the earnings and employment dynamics of early retirees to the dynamics for those who continue to work past age 62. The statisics in Table 4 show that earnings of continuers are about 8 to 10 percent higher than those of early retirees at age 55 . Some of this gap reflects the higher education levels of continuers, as well as some difference in geographic distribution. To net out these effects, we calculate earnings residuals from a regression of log earnings on education, state, and year dummies. By construction, the residuals are of mean zero when continuers and early retirees are combined. For men, the means within the two groups are close to zero, indicating that within education/state/year groups continuers and early retirees have quite similar earnings. But for women there is rougly a 10 percent gap, indicating a stronger relationship between earnings levels and continued employment within education/state/year groups for women than men. Because we have measures of earnings rather than wages, we cannot distinguish whether this difference reflects a greater responsiveness of continued work to wages, or that women who work fewer hours are less likely to continue working past age 62 .

The rich earnings histories available in the LEHD data allow us to examine trajectories relative to age 55. Figure 2 examines current earnings relative to age 55 earnings for our full sample, including those who have zero earnings. Earnings of continuers remain at or above their age-55 earnings until roughly age 63, when they begin to decline. The early retirees have a gradual but continuous decline in earnings from age 55 onward, with a steeper decline at about age 62 and then a flattening out at age 63 .

Figure 3 compares the fraction with positive earnings in a quarter (a rough proxy for participation and labor force attachment) for the two groups. The figure shows that among continuers there is a decline of slightly over 10 percentage points from age 55 to age 62 . The pattern for early retirees is dramatically different with the fraction falling to approximately 30 percent by age 62 . While the gap at age 62 is essentially there by definition, the gap grows steadily with age and the decline in work for the earlier retirees begins well before age 
62.

The similarity in the profiles for early retirees in Figures 2 and 3 suggests that most of the decline in earnings comes about through reduced employment. Figure 4 bears this out: in earnings among those who remain employed, the difference between the early retirees and continuers remains modest until a rather abrupt drop among early retirees close to age 62. The two figures together suggest that employment and episodic attachment to the labor force, rather than earnings conditional on employment, are the primary factors distinguishing the two groups prior to age 62 .

We next investigate whether the early retirees have more frequent job changes ${ }^{6}$ In Figure 5. we indeed find that the share of early retirees who stay with the same primary employer is lower and declines more rapidly with age. Figure 6 shows that the more frequent job changes among early retirees do not arise because their age-55 employers have lower survival rates. Figure 7 compares the earnings of early retirees and continuers by whether or not they had the same employer from age 55 through age 61 . We note the following interesting findings from the figure. First, while it is true that early retirees who change employers have a more rapidly declining earnings trajectory than those who do not change employers, the difference is not particularly large. There is a larger gap between continuers and early retirees who stay with the same employer which suggests to us that earnings losses associated with job changing is not a major contributing factor. The figure in fact illustrates that the group with the largest earnings growth is continuers who changed employers 7 To summarize, we find that the earnings and employment dynamics of early retirees and those who continue to work are notably different. A gap in work and labor force attachment widens well before retirement. The earnings gap, conditional on working, is less pronounced and sharpens at age 61 and later. While the early retirees are more likely to have changed employers, the earnings penalty associated with job changing plays a minor role in accounting for the earnings gap leading up to age 62 .

\section{Employer characteristics}

In this section we compare the characteristics of employers of early retirees and continuers at age 55. The variables we examine here are industry, pension provision, and size. In the

\footnotetext{
${ }^{6}$ Here, and in the following examination of employer and coworker characteristics, we focus on an individual's highest earning job at a particular age (their "primary employer"), when they have more than one employer.

${ }^{7}$ The one caveat here is that we are averaging earnings for those who are working in any given quarter so we do not factor in the possibly greater frequency of non-work episodes among the job changers.
} 
UI earnings data, we know how many establishments a firm has within a state and where they are located. We also have earnings records for each of a firm's employees within a state, but for most states there is no information about which employees work at a particular establishment for firms with more than one. The LEHD database includes multiply imputed links between workers and establishments of such firms that are based on locations of the establishment and the worker's residence along with the timing of a worker's employment and the establishment's time in operation. We use one of these imputations as the link in the current draft.

Table 5 reports the distribution across employer size for the two groups. The last column reports differences between them, which are all significant at the 1 percent level. The table shows that early retirees are less likely to work in smaller establishments (those with less than 100 employees) and much more likely to work in the largest workplaces (those with 500 employers or more). The pattern is less pronounced for women although it goes in the same direction. Part of the explanation may be that larger firms offer more generous pension benefits, making it easier for their employees to retire early. Table 5 shows that employers of early retirees and continuers are about equally likely to offer a retirement plan, but early retirees are substantially more likely to have worked for an employer that has a defined benefit pension plan. But among women, early retirees are less likely to work for an employer that offers a retirement plan, and are only slightly more likely to work for an employer with a defined benefit plan. Larger employers may pay higher wages (and possibly rents) which may lead to pushing workers into early retirement. We plan to explore these alternative "push" and "pull" stories further in the next version of the paper.

In Figures 8 and 9, we compare the industry distribution of employment for the two groups. One question of interest is whether early retirees are over-represented in industries that make heavy physical demands on their employees, or in industries that have experienced relatively rapid technological change that might make older workers' skills out-moded. There is some evidence consistent with the physical demands story - male early retirees are over represented in manufacturing, construction, and transportation and warehousing. Both male and female early retirees are over-represented in public administration, which could reflect physical demands in some public safety jobs, but might also reflect relatively generous pensions. Continuing workers are over-represented in professional, scientific and technical services, and in health care and social assistance. 


\section{Coworker characteristics}

Retirement behavior may be influenced by both the characteristics and retirement behavior of co-workers. We can identify coworkers either as those working at the same location, or more broadly, for the same firm. If the influence occurs through interaction with coworkers, the location of employment (an establishment) is the preferred unit. But the characteristics of coworkers also influence human resource practices that may be set at the firm level, in which case employees at other locations may also be relevant. Here, we are using an establishment as the unit for defining coworkers - we plan to investigate firm-based measures in future drafts.

We calculate co-worker characteristics using the set of co-workers with earnings in two consecutive quarters, where possible. For the first quarter of a year (for example), this should correspond closely to the set of workers employed on March 31/April 1. Using all coworkers associated with an employer in a given quarter will tend to over-represent short-term workers $\unlhd^{8}$ In the following section, we examine co-worker characteristics at the establishment where the individual was working in the quarter after they turn 55.9

Table 6 gives mean co-worker characteristics such as shares by gender, age, and earnings quintiles. The statistics on share female show considerable gender segregation. At age 55, the men in this sample work in establishments where 35-39 percent are female, at a time when women accounted for 46 percent of employment. Even more starkly, women work in largely female establishments, with the typical older woman working in establishments where 62 percent of the workers are female. There is no difference between gender composition of coworkers for female continuers and retirees but, for men, continuers have slightly more female coworkers. Turning to the age composition of co-workers, the table shows that among men, early retirees are less likely to have co-workers who are less than 35, and slightly more likely to have workers in the 35-54 category. For women, the same pattern appears but the differences are quite small.

Finally we look at the share of co-workers in quintiles based on the distribution of annual earnings on primary jobs in the full LEHD database for the year the sample member was 55. The table shows that, among men, early retirees were more likely than continuers to

\footnotetext{
${ }^{8}$ For example, a business could consistently have two employees over the course of the year, with one employee who works all year and the other position filled by a different person in the first and second half of the year. Two-thirds of those employed over the course of the year would be short-term workers, but only one-half of employees are short-term at any point in time.

${ }^{9}$ Because we require three quarters of employment while age 55 (rather than 4), a small share of the sample is not employed in that quarter, in which case we use the next quarter. There are also a small share of employers who have no employees with employment in both of the quarters in question, in which case we use all employees in the quarter. This can happen with new or seasonal businesses.
} 
have highly paid co-workers at age 55 (quintile 4 and quintile 5). Again, the differences for women are much smaller. Figure 10 plots the average ratio of own pay to coworker pay for the two groups, following the evolution of that ratio from age 55 to 63 . The plot makes clear that at age 55 the continuers are more highly paid relative to their coworkers than are the (eventual) early retirees. Continuers remain highly paid relative to their coworkers, with the advantage falling only modestly between 55 and 63 . In contrast, the early retirees start out with a smaller advantage which declines continuously through age 63, passing the even mark at about age 60 . Note that our sample is 55 years old when we first measure their earnings relative to co-workers so that the premium they enjoy initially may be largely due to age. As in Figure 4, we include only those employed in a particular quarter. That figure illustrated that earnings among the employed did not fall among the early retirees until about age 61, so the decline in relative earnings occurs because the early retirees have slower earnings growth than do their coworkers.

In Table 7, we look more narrowly at coworkers who might be more likely to be peers, taking those who are age 55 or older and are the same gender as the sample member. The majority of older workers do work with peers, according to this definition, and early retirees are slightly more likely to work with peers than continuers. The second line shows that for both men and women there is little difference between the two groups in the level of coworker earnings. But continuers are somewhat higher in their peers' earnings distribution than are early retirees.

In Tables 8 and 9 we estimate a series of linear probability models to examine to what extent employer and coworker characteristics matter when we control for other factors. We regress early retirement on state, year, education, marital status and various workplace characteristics including industry, establishment size, pension dummies, gender and age shares for co-workers, co-worker earnings, and own earnings. As the table shows, education is a strong predictor of early retirement, particularly for men, with male college graduates having a 15 percentage point lower probability of early retirement than those who did not finish high school. Including workplace characteristics has little effect on the educatio coefficients and they remain large even when we control for earnings. Own earnings reduce the likelihood of early retirement for men while co-worker earnings increase it. For women, greater own earnings are associated with later retirement but not greater co-worker earnings. Interestingly, the employer size effect remains quite positive even with other controls such as industry and pensions in the regression. Young coworkers and coworkers of the opposite sex (less sex-segregated workplaces) are associated with lower retirement rates, with the younger co-worker effect being fairly large. We plan to explore in the future whether younger age of 
co-workers is associated with growth or age of the firm.

The last column examines the interaction of own and co-worker earnings. When the interaction is included, the main effect of co-worker earnings is negative while the interaction is positive. To make the implied effects clearer, in Figures 11 we plot out predicted early retirement rates as a function of own earnings for men and for women based on this specification. The three lines in the graph represent different levels of coworker pay. This makes it clear that the marginal increase in retirement rates with coworker earnings is slightly larger at higher levels of own earnings, though the differences are quite modest.

\section{Conclusions}

In this study we use linked employer-employee data to measure characteristics of employment at age 55, and then examine how those characteristics differ between those who retire around age 62 and those who work past that age. We find that at age 55, early retirees are more likely than continuers to be working in sectors such as manufacturing and construction, which lends credence to the theory that physically demanding jobs contribute to earlier retirement. Early retirees, however, are also more likely to work for employers with defined benefit pension plans, and to be in public administration and education services (among women) which suggests that generous pension coverage may also help account for earlier retirement. Using a simple linear probability model of early retirement, we find that education is a strong predictor of early retirement even with the addition of workplace controls. We find a positive relationship between establishment size and early retirement, even when controlling for pension coverage and industry of employment. Co-worker characteristics are also related to early retirement probability. Younger co-workers are associated with a reduction in the probability of early retirement. One potential explanation is that early retirees are less likely to be working in growing firms - a possibility we plan to explore in the next draft. Higher

own earnings reduce early retirement, but for most levels of own earnings, higher co-worker earnings increase the probability of retirement. 


\section{References}

Abowd, J. M., L. Vilhuber, K. McKinney, K. Sandusky, B. Stephens, F. AnDersson, M. Roemer, and S. Woodcock (2006): "The LEHD Infrastructure Files and the Creation of the Quarterly Workforce Indicators," LEHD technical paper, U.S. Census Bureau.

Abraham, K., J. Haltiwanger, K. Sandusky, and J. Spletzer (2009): "Exploring Differences in Employment between Household and Establishment Data," Discussion Paper CES 09-09, U.S. Census Bureau.

Ahituv, A., and J. Zeira (2011): "Technological Progress and Early Retirement," The Economic Journal, 121, 171-193.

Autor, D., F. Levy, and R. Murnane (2003): "The Skill Content of Recent Technological Change: An Empirical Exploration," The Quarterly Journal of Economics, 118, 1279-1333.

Bartel, A. P., And N. Sicherman (1993): "Technological Change and Retirement Decisions of Older Workers," Journal of Labor Economics, 11, 162-183.

Blau, D., And R. Goodstein (2010): "Can Social Security Explain Trends in the Labor Force Participation of Older Men in the United States?," Journal of Human Resources, $45,328-63$.

Brown, K., and R. Laschever (2010): "When They're Sixty-Four: Peer Effects and the Timing of Retirement," Working Paper, University of Illinois at Urbana-Champaign.

Bureau of Labor Statistics, U. S. (1997): "Handbook of Methods, Chapter 5," .

Card, D., A. Mas, E. Moretti, and E. Saez (2011): "Inequality at Work: The Effect of Peer Salaries on Job Satisfaction," Discussion Paper 16396, NBER.

Chalmers, J., and W. T. Johnson (2008): "Who Determines When You Retire? Peer Effects and Retirement," Working Paper, University of Oregon.

Gustman, A., And T. Steinmeier (2006): "How Changes in Social Security Affect Retirement Trends," Discussion Paper 2006-127, Michigan Retirement Research Center.

Juhn, C., And S. Potter (2008): "Interactions in the Labor Market Behavior of Couples Over the Life Course," Working Paper, NBER Retirement Research Center. 
Maestas, N., and J. Zissimopoulos (2010): "How Longer Work Lives Ease the Crunch of Population Aging," Journal of Economic Perspectives, 24, 139-160.

Munnell, A., And S. SASs (2008): "The Labor Supply of Older American Men," Labor Supply in the New Century, Federal Reserve Bank of Boston. 


\section{Table 1: Match to LEHD earnings for age 55 ACS respondents}

\begin{tabular}{lcc}
\hline \hline Status of match & Men & Women \\
\hline Not enough information to match & 0.07 & 0.07 \\
Not matched and reported: & & \\
$\quad$ Federal employment & 0.03 & 0.02 \\
Unincorporated self-employment & 0.07 & 0.04 \\
Non-federal wage/salary employment in non-LEHD state & 0.07 & 0.07 \\
$\quad$ Non-federal wage/salary employment in LEHD state & 0.09 & 0.09 \\
Matched to LEHD earnings records & 0.67 & 0.71 \\
\hline \hline
\end{tabular}

Notes: Sample is 55-year olds in 2005-2008 ACS who report working in last 12 months. The sample is matched to LEHD earnings records for the 4-quarter period ending in the quarter with ACS response date.

Table 2: Characteristics by match status for age 55 ACS respondents

\begin{tabular}{llcc}
\hline \hline & & Not matched & Matched \\
\hline Men & & & \\
\multicolumn{2}{l}{ Education: } & 0.10 & 0.08 \\
& Less than HS & 0.25 & 0.25 \\
& HS graduate & 0.29 & 0.30 \\
& Some college & 0.35 & 0.37 \\
& College grad & & 63,830 \\
Income: & & 47,420 & 71,647 \\
& Wage and salary income & 65,709 & \\
Women & Total income & & 0.06 \\
Education: & & & 0.27 \\
& Less than HS & 0.09 & 0.32 \\
& HS graduate & 0.28 & 0.34 \\
& Some college & 0.30 & 38,188 \\
Income: & College grad & 0.33 & 41,650 \\
& Wage and salary income & & \\
& Total income & 33,148 & \\
\hline \hline
\end{tabular}

Notes: Sample is 55-year olds in 2005-2008 ACS who report working in last 12 months. The sample is matched to LEHD earnings records for the 4-quarter period ending in the quarter with ACS response date. Education and earnings measures are from ACS. 
Table 3: Differences in employee characteristics at age 63

\begin{tabular}{|c|c|c|c|}
\hline & Continuers & Retirees & Difference \\
\hline \multicolumn{4}{|l|}{ Men } \\
\hline \multicolumn{4}{|l|}{ Education } \\
\hline Less than HS & 0.106 & 0.154 & $-0.048^{* * *}$ \\
\hline HS graduate & 0.246 & 0.309 & $-0.063^{* * *}$ \\
\hline Some college & 0.261 & 0.261 & 0.000 \\
\hline College grad & 0.387 & 0.276 & $0.111^{* * *}$ \\
\hline \multicolumn{4}{|l|}{ Marital status } \\
\hline Married & 0.818 & 0.772 & $0.045^{* * *}$ \\
\hline Widowed & 0.021 & 0.035 & $-0.014^{* * *}$ \\
\hline Divorced/separated & 0.124 & 0.144 & $-0.019^{* * *}$ \\
\hline Never married & 0.037 & 0.049 & $-0.012^{* * *}$ \\
\hline \multicolumn{4}{|l|}{ Income shares } \\
\hline Wage/salary earnings & 0.809 & 0.131 & $0.678 * * *$ \\
\hline Social Security & 0.042 & 0.363 & $-0.321 * * *$ \\
\hline Retirement income & 0.065 & 0.316 & $-0.252^{* * *}$ \\
\hline \multicolumn{4}{|l|}{ Women } \\
\hline \multicolumn{4}{|l|}{ Education } \\
\hline Less than HS & 0.089 & 0.128 & $-0.039 * * *$ \\
\hline HS graduate & 0.318 & 0.341 & $-0.023^{* * *}$ \\
\hline Some college & 0.309 & 0.277 & $0.033^{* * *}$ \\
\hline College grad & 0.284 & 0.255 & $0.029 * * *$ \\
\hline \multicolumn{4}{|l|}{ Marital status } \\
\hline Married & 0.557 & 0.651 & $-0.095^{* * *}$ \\
\hline Widowed & 0.116 & 0.114 & $0.002^{* * *}$ \\
\hline Divorced/separated & 0.270 & 0.184 & $0.087^{* * *}$ \\
\hline Never married & 0.057 & 0.051 & $0.006^{* * *}$ \\
\hline \multicolumn{4}{|l|}{ Income shares } \\
\hline Wage/salary earnings & 0.833 & 0.123 & $0.711^{* * *}$ \\
\hline Social Security & 0.064 & 0.441 & $-0.378^{* * *}$ \\
\hline Retirement income & 0.043 & 0.240 & $-0.196^{* * *}$ \\
\hline
\end{tabular}

Notes: Variables come from the ACS, and are measured at time of ACS interview (age between 62.5 and 63.5). 
Table 4: Differences in own earnings at age 55

\begin{tabular}{cccc}
\hline \hline & Continuers & Retirees & Difference \\
\hline Men & & & \\
Earnings on main job & 70,271 & 64,225 & $6,047^{* * *}$ \\
Earnings on all jobs & 73,962 & 66,978 & $6,984^{* * *}$ \\
Earnings residual & 0.004 & -0.007 & $0.011^{* * *}$ \\
Women & & & \\
Earnings on main job & 34,093 & 31,362 & $2,731^{* * *}$ \\
Earnings on all jobs & 36,001 & 32,667 & $3,334^{* * *}$ \\
Earnings residual & 0.045 & -0.064 & $0.109^{* * *}$ \\
\hline \hline
\end{tabular}

Notes: Earnings measures from LEHD database. Residuals based on regressions by gender of log earnings on main job on dummies for state, year, and education group.

Table 5: Differences in characteristics of age-55 employer

\begin{tabular}{lccc}
\hline \hline & Continuers & Retirees & Difference \\
\hline $\begin{array}{l}\text { Men } \\
\text { Establishment size }\end{array}$ & & & \\
$\quad<9$ & 0.148 & 0.090 & $0.058^{* * *}$ \\
$\quad 10-19$ & 0.086 & 0.069 & $0.017^{* * *}$ \\
$20-49$ & 0.140 & 0.111 & $0.029^{* * *}$ \\
$50-99$ & 0.120 & 0.109 & $0.011^{* * *}$ \\
$\quad 100-499$ & 0.247 & 0.262 & $-0.015^{* * *}$ \\
$\quad>=500$ & 0.258 & 0.359 & $-0.101^{* * *}$ \\
Offers retirement plan(s) & 0.373 & 0.371 & $0.002^{*}$ \\
Offers defined benefit pension & 0.125 & 0.188 & $-0.063^{* * *}$ \\
Women & & & \\
Establishment size & & & \\
$\quad<9$ & 0.130 & 0.114 & $0.016^{* * *}$ \\
$10-19$ & 0.080 & 0.066 & $0.015^{* * *}$ \\
$20-49$ & 0.123 & 0.107 & $0.017^{* * *}$ \\
$50-99$ & 0.107 & 0.111 & $-0.005^{* * *}$ \\
$100-499$ & 0.249 & 0.255 & $-0.006^{* * *}$ \\
$>=500$ & 0.310 & 0.347 & $-0.037^{* * *}$ \\
Offers retirement plan & 0.293 & 0.260 & $0.033^{* * *}$ \\
Offers defined benefit pension & 0.090 & 0.104 & $-0.015^{* * *}$ \\
\hline \hline
\end{tabular}

Notes: Measures for main employer at age 55. Measures based on LEHD and Form 5500 information. 
Table 6: Differences in coworker characteristics at age 55

\begin{tabular}{|c|c|c|c|}
\hline & Continuers & "Retirees & Difference \\
\hline \multicolumn{4}{|l|}{ Men } \\
\hline \multicolumn{4}{|l|}{ Share of coworkers who are: } \\
\hline Women & 0.387 & 0.351 & $0.036^{* * *}$ \\
\hline$<35$ & 0.313 & 0.287 & $0.026^{* * *}$ \\
\hline $35-54$ & 0.536 & 0.557 & $-0.021^{* * *}$ \\
\hline$>=55$ & 0.151 & 0.156 & $-0.005^{* * *}$ \\
\hline \multicolumn{4}{|c|}{ Share of coworkers by annual earnings quintile: } \\
\hline Bottom quintile & 0.146 & 0.132 & $0.013^{* * *}$ \\
\hline Quintile 2 & 0.159 & 0.138 & $0.021^{* * *}$ \\
\hline Quintile 3 & 0.199 & 0.175 & $0.025^{* * *}$ \\
\hline Quintile 4 & 0.233 & 0.241 & $-0.008^{* * *}$ \\
\hline Top quintile & 0.258 & 0.306 & $-0.048^{* * *}$ \\
\hline Average annual earnings & 41,574 & 43,955 & $-2,382^{* * *}$ \\
\hline Share paid less than sample member & 0.68 & 0.62 & $0.06^{* * *}$ \\
\hline \multicolumn{4}{|l|}{ Women } \\
\hline \multicolumn{4}{|l|}{ Share of coworkers who are: } \\
\hline Women & 0.618 & 0.617 & $0.001^{*}$ \\
\hline$<35$ & 0.322 & 0.310 & $0.011^{* * *}$ \\
\hline $35-54$ & 0.519 & 0.525 & $-0.006^{* * *}$ \\
\hline$>=55$ & 0.159 & 0.165 & $-0.005^{* * *}$ \\
\hline \multicolumn{4}{|c|}{ Share of coworkers by annual earnings quintile: } \\
\hline Bottom quintile & 0.203 & 0.216 & $-0.013^{* * *}$ \\
\hline Quintile 2 & 0.203 & 0.200 & $0.003^{* * *}$ \\
\hline Quintile 3 & 0.202 & 0.189 & $0.013^{* * *}$ \\
\hline Quintile 4 & 0.199 & 0.198 & $0.001^{* * *}$ \\
\hline Top quintile & 0.188 & 0.191 & $-0.002^{* * *}$ \\
\hline Average annual earnings & 34,599 & 33,167 & $1,431^{* * *}$ \\
\hline Share paid less than sample member & 0.54 & 0.51 & $0.04^{* * *}$ \\
\hline
\end{tabular}

Notes: Measures for employees of main employer in year respondent was age 55. For most sample members, measured as of the quarter after turned age 55 and including only employees with earnings in both that quarter and the one before it. Where that was not possible, measured for another quarter of year aged 55 and/or using all employees with earnings in quarter of measurement. 
Table 7: Differences in characteristics of peers at age 55

\begin{tabular}{lccc}
\hline \hline & Continuers & Retirees & Difference \\
\hline Men & & & \multirow{2}{*}{$0.06^{* * *}$} \\
Has coworkers over age 55/same gender & 0.84 & 0.90 & -83 \\
Average annual earnings of peers & 59,826 & 59,909 & $0.05^{* * *}$ \\
Share of peers paid less than sample member & 0.59 & 0.55 & \\
Women & & & $-0.02^{* * *}$ \\
Has coworkers over age 55/same gender & 0.84 & 0.87 & $233^{* * *}$ \\
Average annual earnings of peers & 28,849 & 28,616 & $0.04^{* * *}$ \\
Share of peers paid less than sample member & 0.60 & 0.55 &
\end{tabular}

Notes: Measures for coworkers aged 55 or more, of same gender, working for sample member's age-55 employer. 
Table 8: Linear probability models of early retirement, Men

\begin{tabular}{|c|c|c|c|c|}
\hline & (1) & (2) & (3) & $\overline{(4)}$ \\
\hline High school graduate & $\begin{array}{c}-0.034^{* * *} \\
(0.008)\end{array}$ & $\begin{array}{c}-0.053^{* * *} \\
(0.008)\end{array}$ & $\begin{array}{c}-0.048^{* * *} \\
(0.008)\end{array}$ & $\begin{array}{c}-0.048^{* * *} \\
(0.008)\end{array}$ \\
\hline Some College & $\begin{array}{c}-0.086^{* * *} \\
(0.009)\end{array}$ & $\begin{array}{c}-0.103^{* * *} \\
(0.009)\end{array}$ & $\begin{array}{c}-0.093^{* * *} \\
(0.009)\end{array}$ & $\begin{array}{c}-0.093^{* * *} \\
(0.009)\end{array}$ \\
\hline College graduate & $\begin{array}{c}-0.153^{* * *} \\
(0.008)\end{array}$ & $\begin{array}{c}-0.164^{* * *} \\
(0.009)\end{array}$ & $\begin{array}{c}-0.140^{* * *} \\
(0.009)\end{array}$ & $\begin{array}{c}-0.143^{* * *} \\
(0.009)\end{array}$ \\
\hline Widowed & $\begin{array}{c}0.113^{* * *} \\
(0.015)\end{array}$ & $\begin{array}{c}0.116^{* * *} \\
(0.015)\end{array}$ & $\begin{array}{c}0.113^{* * *} \\
(0.015)\end{array}$ & $\begin{array}{c}0.113^{* * *} \\
(0.015)\end{array}$ \\
\hline Divorced/separated & $\begin{array}{c}0.041^{* * *} \\
(0.008)\end{array}$ & $\begin{array}{c}0.046^{* * *} \\
(0.007)\end{array}$ & $\begin{array}{c}0.041^{* * *} \\
(0.007)\end{array}$ & $\begin{array}{c}0.041^{* * *} \\
(0.007)\end{array}$ \\
\hline Never married & $\begin{array}{c}0.062^{* * *} \\
(0.013)\end{array}$ & $\begin{array}{c}0.070^{* * *} \\
(0.013)\end{array}$ & $\begin{array}{c}0.059^{* * *} \\
(0.013)\end{array}$ & $\begin{array}{c}0.057^{* * *} \\
(0.013)\end{array}$ \\
\hline Establishment size 10-19 & & $\begin{array}{l}0.035^{* *} \\
(0.011)\end{array}$ & $\begin{array}{l}0.035^{* *} \\
(0.011)\end{array}$ & $\begin{array}{l}0.036^{* *} \\
(0.011)\end{array}$ \\
\hline Establishment size 20-49 & & $\begin{array}{c}0.037^{* * *} \\
(0.010)\end{array}$ & $\begin{array}{c}0.036^{* * *} \\
(0.010)\end{array}$ & $\begin{array}{c}0.038^{* * *} \\
(0.010)\end{array}$ \\
\hline Establishment size 50-99 & & $\begin{array}{c}0.061^{* * *} \\
(0.011)\end{array}$ & $\begin{array}{c}0.061^{* * *} \\
(0.011)\end{array}$ & $\begin{array}{c}0.063^{* * *} \\
(0.011)\end{array}$ \\
\hline Establishment size 100-499 & & $\begin{array}{c}0.083^{* * *} \\
(0.010)\end{array}$ & $\begin{array}{c}0.083^{* * *} \\
(0.010)\end{array}$ & $\begin{array}{c}0.085^{* * *} \\
(0.010)\end{array}$ \\
\hline Establishment size $>=500$ & & $\begin{array}{c}0.146^{* * *} \\
(0.010)\end{array}$ & $\begin{array}{c}0.146^{* * *} \\
(0.010)\end{array}$ & $\begin{array}{c}0.148^{* * *} \\
(0.010)\end{array}$ \\
\hline Coworker share female & & $\begin{array}{l}-0.032^{*} \\
(0.013)\end{array}$ & $\begin{array}{c}-0.027^{*} \\
(0.013)\end{array}$ & $\begin{array}{l}-0.024 \\
(0.013)\end{array}$ \\
\hline Coworker share $<35$ yrs old & & $\begin{array}{c}-0.128^{* * *} \\
(0.021)\end{array}$ & $\begin{array}{c}-0.117^{* * *} \\
(0.021)\end{array}$ & $\begin{array}{c}-0.114^{\text {*** }} \\
(0.021)\end{array}$ \\
\hline Coworker share $35-54$ & & $\begin{array}{l}-0.007 \\
(0.022)\end{array}$ & $\begin{array}{c}-0.004 \\
(0.022)\end{array}$ & $\begin{array}{l}-0.003 \\
(0.022)\end{array}$ \\
\hline Log(coworker annual earnings) & & $\begin{array}{c}0.028^{* * *} \\
(0.005)\end{array}$ & $\begin{array}{c}0.051^{* * *} \\
(0.006)\end{array}$ & $\begin{array}{c}-0.139^{* * *} \\
(0.034)\end{array}$ \\
\hline Employer has retirement plan(s) & & $\begin{array}{c}-0.052^{* * *} \\
(0.007)\end{array}$ & $\begin{array}{c}-0.050^{* * *} \\
(0.007)\end{array}$ & $\begin{array}{c}-0.049^{* * *} \\
(0.007)\end{array}$ \\
\hline Employer has DB pension & & $\begin{array}{c}0.095^{* * *} \\
(0.009)\end{array}$ & $\begin{array}{c}0.095^{* * *} \\
(0.009)\end{array}$ & $\begin{array}{c}0.093^{* * *} \\
(0.009)\end{array}$ \\
\hline Log(own annual earnings) & & & $\begin{array}{c}-0.036^{* * *} \\
(0.004)\end{array}$ & $\begin{array}{r}-0.223^{* * *} \\
(0.033)\end{array}$ \\
\hline Interaction of own/coworker earnings & & & & $\begin{array}{c}0.018^{* * *} \\
(0.003)\end{array}$ \\
\hline Observations & 39,836 & 39,836 & 39,836 & 39,836 \\
\hline
\end{tabular}


Table 9: Linear probability models of early retirement, Women

\begin{tabular}{|c|c|c|c|c|}
\hline & (1) & (2) & 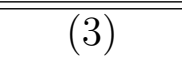 & 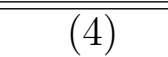 \\
\hline High school graduate & $\begin{array}{c}-0.075^{* * *} \\
(0.009)\end{array}$ & $\begin{array}{c}-0.072^{* * *} \\
(0.009)\end{array}$ & $\begin{array}{c}-0.065^{* * *} \\
(0.009)\end{array}$ & $\begin{array}{c}-0.064^{* * *} \\
(0.009)\end{array}$ \\
\hline Some College & $\begin{array}{c}-0.117^{* * *} \\
(0.009)\end{array}$ & $\begin{array}{c}-0.109^{* * *} \\
(0.010)\end{array}$ & $\begin{array}{c}-0.094^{* * *} \\
(0.010)\end{array}$ & $\begin{array}{c}-0.094^{* * *} \\
(0.010)\end{array}$ \\
\hline College graduate & $\begin{array}{c}-0.107^{* * *} \\
(0.009)\end{array}$ & $\begin{array}{c}-0.129^{* * *} \\
(0.010)\end{array}$ & $\begin{array}{c}-0.091^{* * *} \\
(0.010)\end{array}$ & $\begin{array}{c}-0.096^{* * *} \\
(0.010)\end{array}$ \\
\hline Widowed & $\begin{array}{c}-0.059^{* * *} \\
(0.008)\end{array}$ & $\begin{array}{c}-0.058^{* * *} \\
(0.008)\end{array}$ & $\begin{array}{c}-0.057^{* * *} \\
(0.008)\end{array}$ & $\begin{array}{c}-0.057^{* * *} \\
(0.008)\end{array}$ \\
\hline Divorced/separated & $\begin{array}{c}-0.136^{* * *} \\
(0.006)\end{array}$ & $\begin{array}{c}-0.134^{* * *} \\
(0.006)\end{array}$ & $\begin{array}{c}-0.129^{* * *} \\
(0.006)\end{array}$ & $\begin{array}{c}-0.130^{* * *} \\
(0.006)\end{array}$ \\
\hline Never married & $\begin{array}{c}-0.063^{* * *} \\
(0.012)\end{array}$ & $\begin{array}{c}-0.064^{* * *} \\
(0.012)\end{array}$ & $\begin{array}{c}-0.059^{* * *} \\
(0.012)\end{array}$ & $\begin{array}{c}-0.061^{* * *} \\
(0.012)\end{array}$ \\
\hline Establishment size 10-19 & & $\begin{array}{c}0.005 \\
(0.012)\end{array}$ & $\begin{array}{c}0.007 \\
(0.012)\end{array}$ & $\begin{array}{c}0.008 \\
(0.012)\end{array}$ \\
\hline Establishment size $20-49$ & & $\begin{array}{c}0.023^{*} \\
(0.011)\end{array}$ & $\begin{array}{l}0.029^{* *} \\
(0.011)\end{array}$ & $\begin{array}{l}0.031^{* *} \\
(0.011)\end{array}$ \\
\hline Establishment size 50-99 & & $\begin{array}{c}0.056^{* * *} \\
(0.011)\end{array}$ & $\begin{array}{c}0.063^{* * *} \\
(0.011)\end{array}$ & $\begin{array}{c}0.065^{* * *} \\
(0.011)\end{array}$ \\
\hline Establishment size 100-499 & & $\begin{array}{c}0.055^{* * *} \\
(0.010)\end{array}$ & $\begin{array}{c}0.062^{* * *} \\
(0.010)\end{array}$ & $\begin{array}{c}0.064^{* * *} \\
(0.010)\end{array}$ \\
\hline Establishment size $>=500$ & & $\begin{array}{c}0.085^{* * *} \\
(0.010)\end{array}$ & $\begin{array}{c}0.095^{* * *} \\
(0.010)\end{array}$ & $\begin{array}{c}0.094^{* * *} \\
(0.010)\end{array}$ \\
\hline Coworker share female & & $\begin{array}{c}0.031^{*} \\
(0.015)\end{array}$ & $\begin{array}{c}0.029 \\
(0.015)\end{array}$ & $\begin{array}{c}0.034^{*} \\
(0.015)\end{array}$ \\
\hline Coworker share $<35$ yrs old & & $\begin{array}{c}-0.067^{* *} \\
(0.021)\end{array}$ & $\begin{array}{c}-0.051^{*} \\
(0.021)\end{array}$ & $\begin{array}{l}-0.044^{*} \\
(0.021)\end{array}$ \\
\hline Coworker share $35-54$ & & $\begin{array}{c}0.008 \\
(0.022)\end{array}$ & $\begin{array}{c}0.022 \\
(0.022)\end{array}$ & $\begin{array}{c}0.024 \\
(0.022)\end{array}$ \\
\hline Log(coworker annual earnings) & & $\begin{array}{c}-0.020^{* * *} \\
(0.005)\end{array}$ & $\begin{array}{c}0.007 \\
(0.006)\end{array}$ & $\begin{array}{c}-0.312^{* * *} \\
(0.039)\end{array}$ \\
\hline Employer has retirement plan(s) & & $\begin{array}{c}-0.048^{* * *} \\
(0.007)\end{array}$ & $\begin{array}{c}-0.049^{* * *} \\
(0.007)\end{array}$ & $\begin{array}{c}-0.048^{* * *} \\
(0.007)\end{array}$ \\
\hline Employer has DB pension & & $\begin{array}{c}0.081^{* * *} \\
(0.010)\end{array}$ & $\begin{array}{c}0.085^{* * *} \\
(0.010)\end{array}$ & $\begin{array}{c}0.082^{* * *} \\
(0.010)\end{array}$ \\
\hline Log(own annual earnings) & & & $\begin{array}{c}-0.057^{* * *} \\
(0.004)\end{array}$ & $\begin{array}{c}-0.383^{* * *} \\
(0.040)\end{array}$ \\
\hline Interaction of own/coworker earnings & & & & $\begin{array}{c}0.033^{* * *} \\
(0.004)\end{array}$ \\
\hline Observations & 39,269 & 39,269 & 39,269 & 39,269 \\
\hline
\end{tabular}


Figure 1: Differences in employment profiles by reported employment status

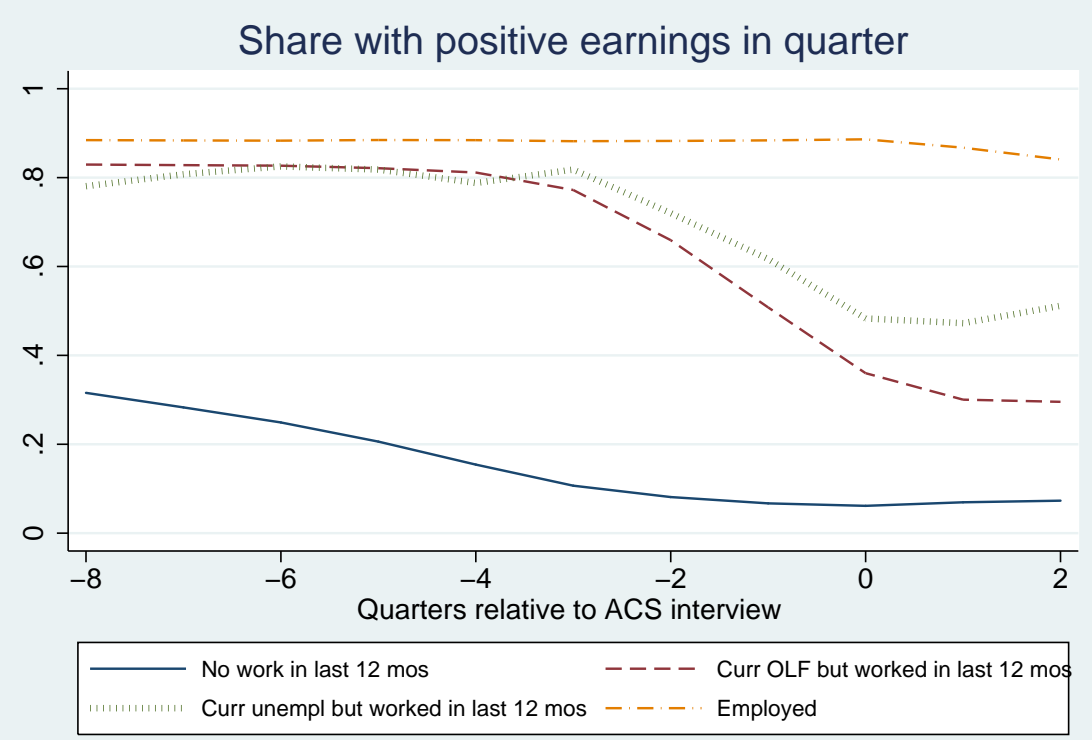

Sample: 1942-1943 cohorts 
Figure 2: Earnings profiles age 55 to 63 relative to own age- 55 earnings

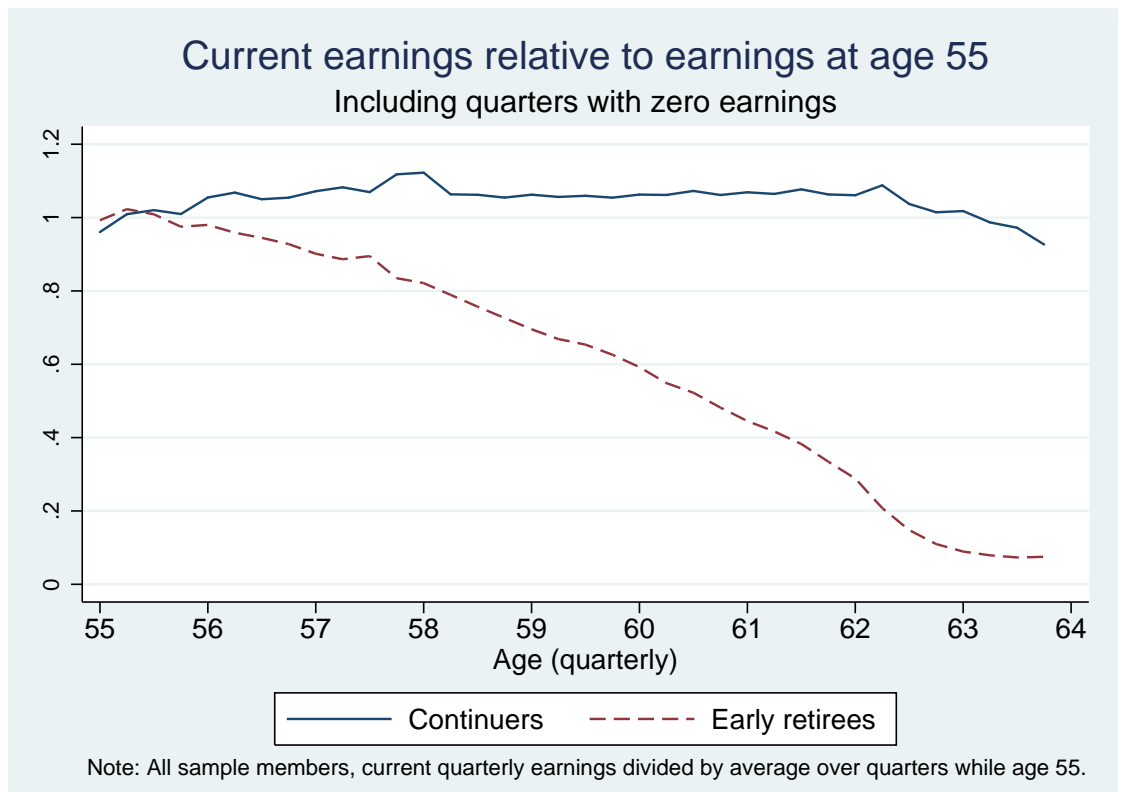

Figure 3: Employment profiles from age 55 to 63, by retirement status at 62

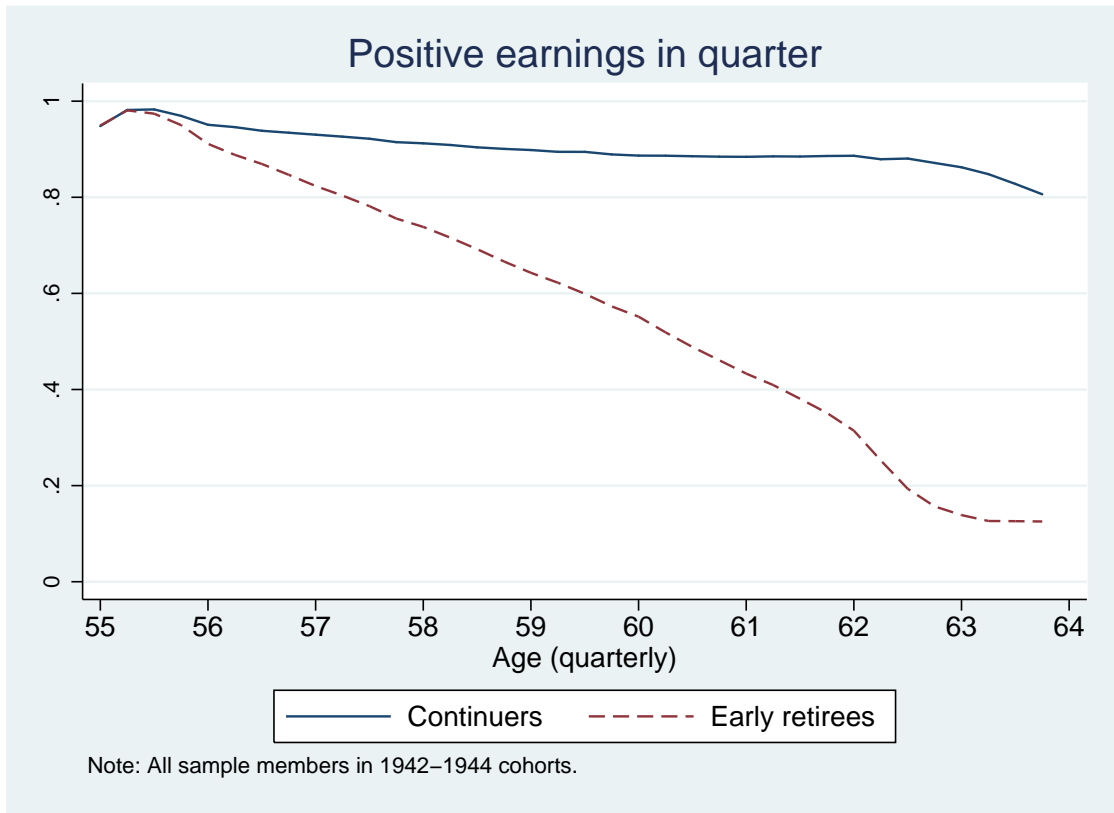


Figure 4: Earnings profiles relative to own age-55 earnings, conditional on employment

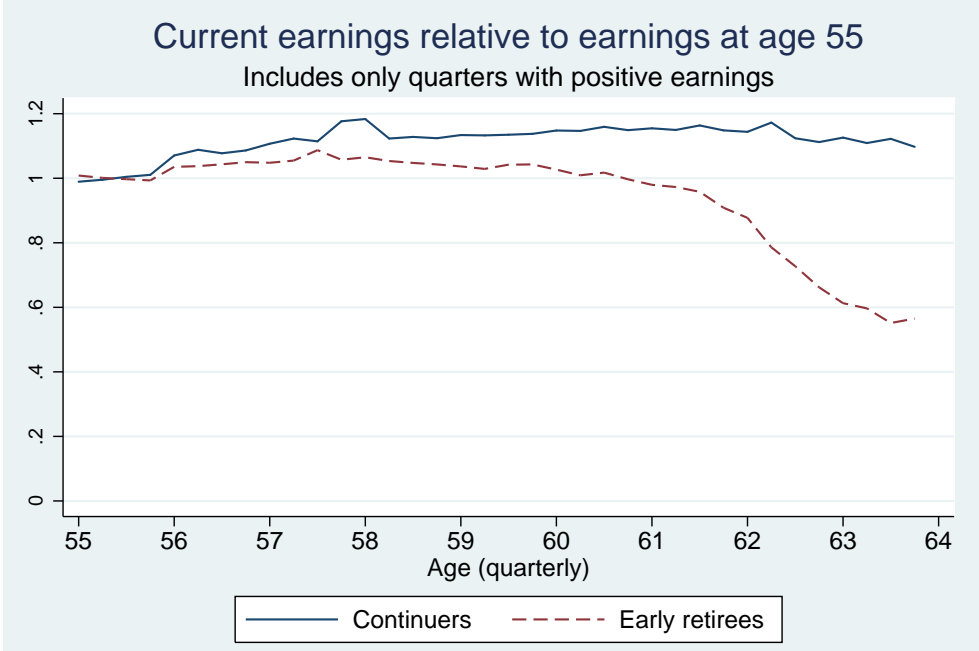

Note: Employed sample members, current quarterly earnings divided by average over quarters worked while aged 55

Figure 5: Job mobility ages 55 to 63

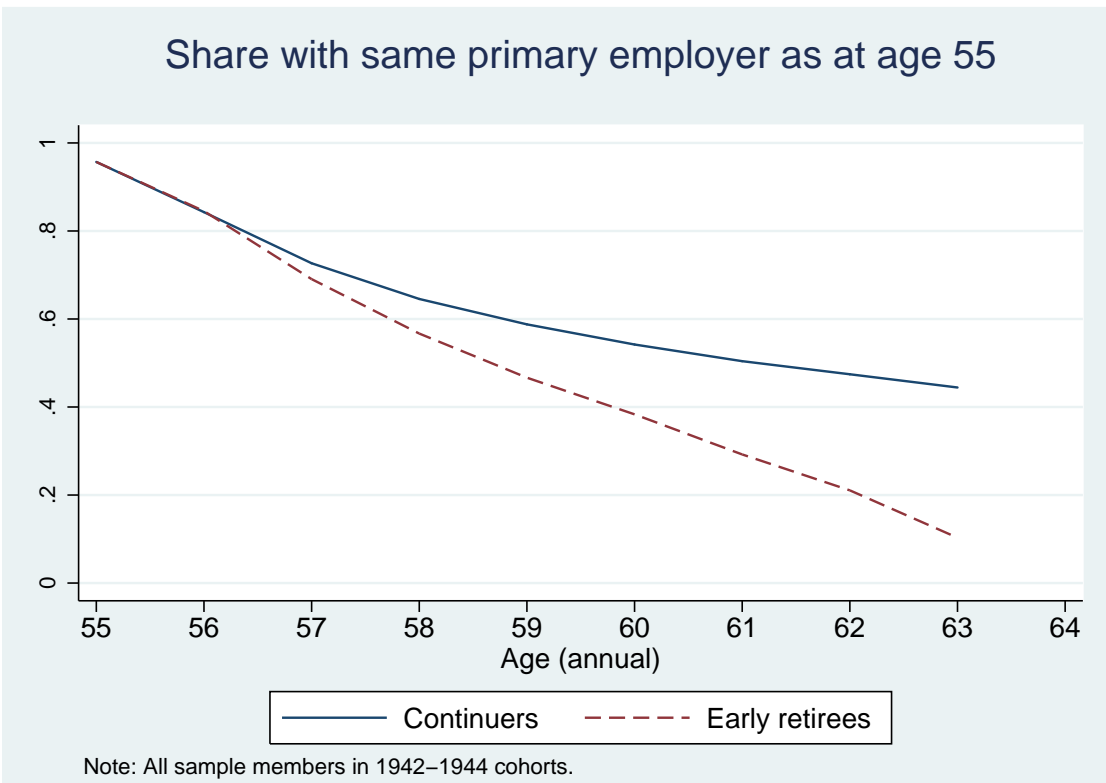


Figure 6: Survival rates for age-55 primary employer

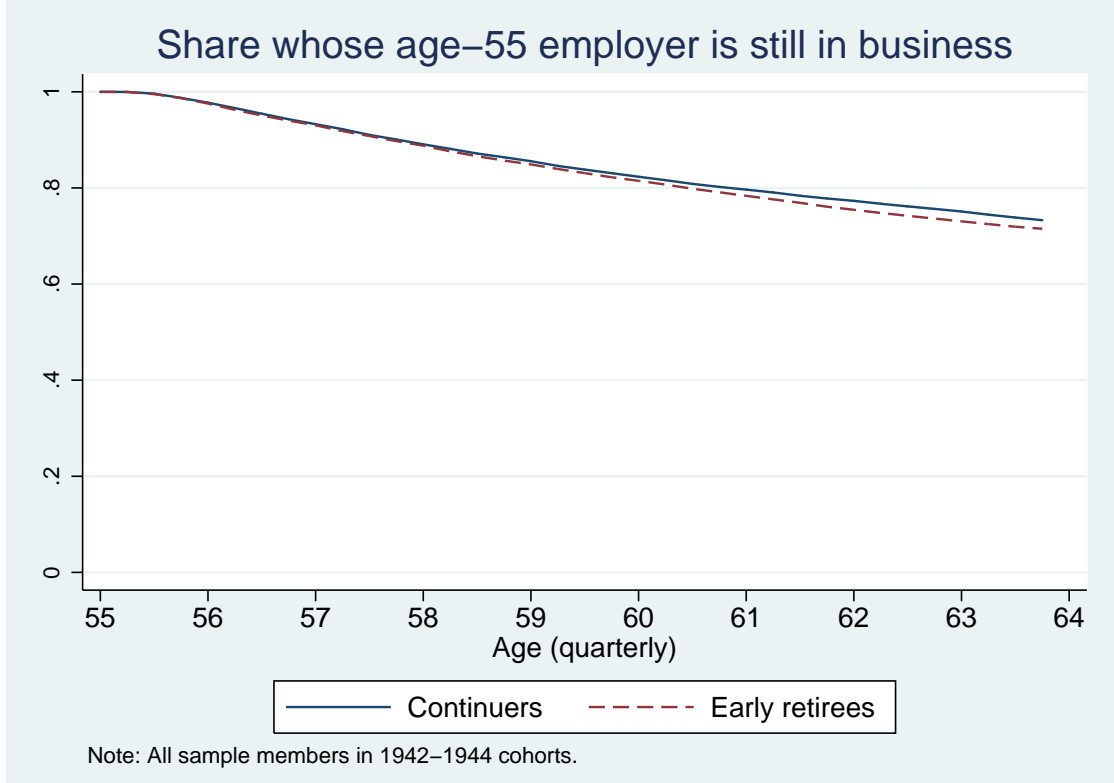

Figure 7: Earnings profiles by whether stay with one employer or not

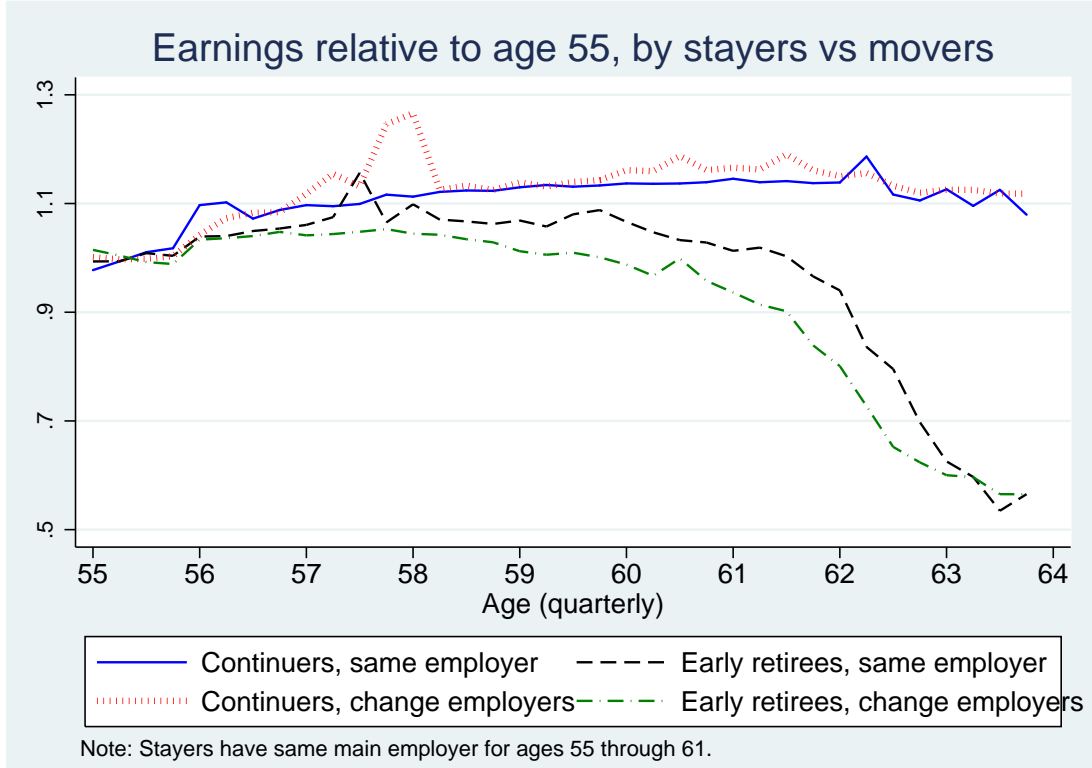


Figure 8: Differences in employment shares by industry sector for men at age 55

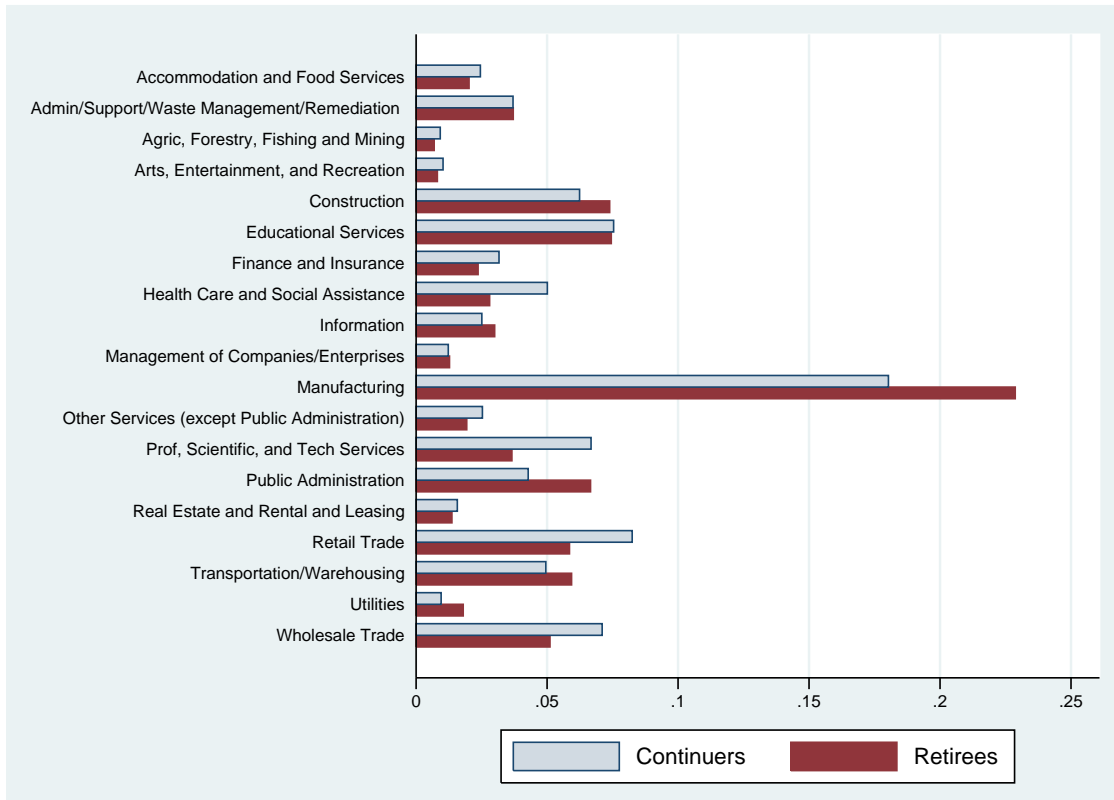

Figure 9: Differences in employment shares by industry sector for women at age 55

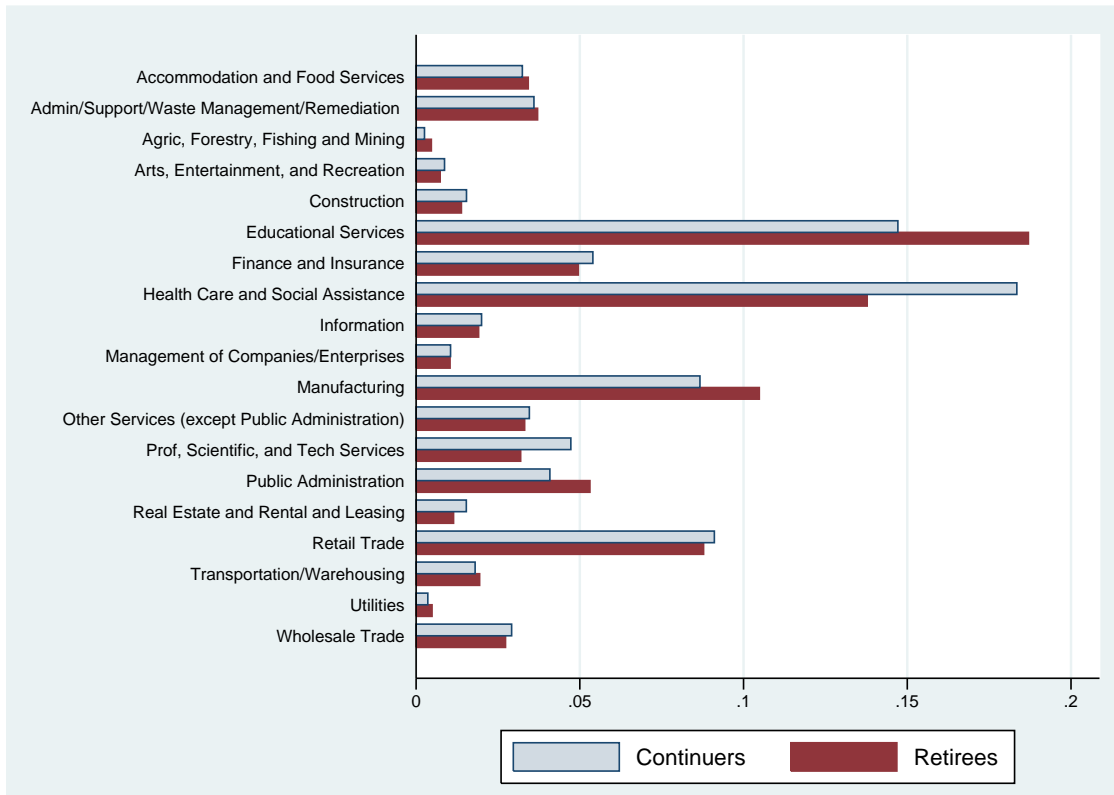


Figure 10: Earnings relative to coworkers

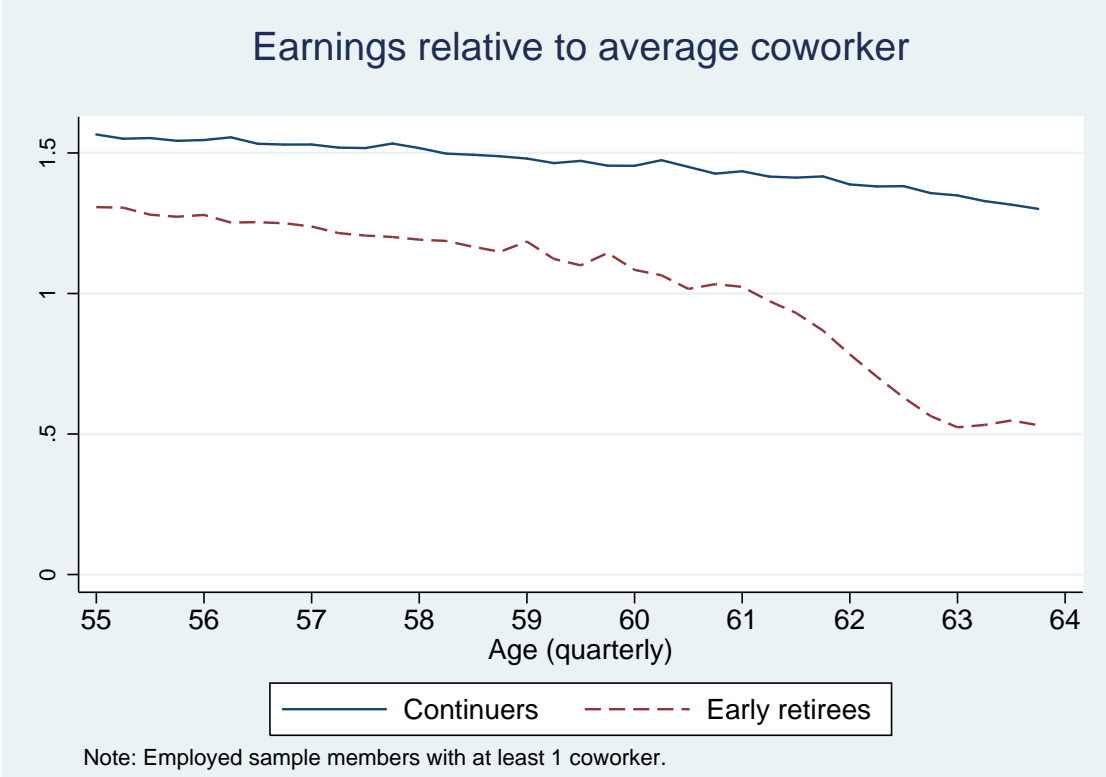


Figure 11: Predicted effects of own/coworker earnings with interaction

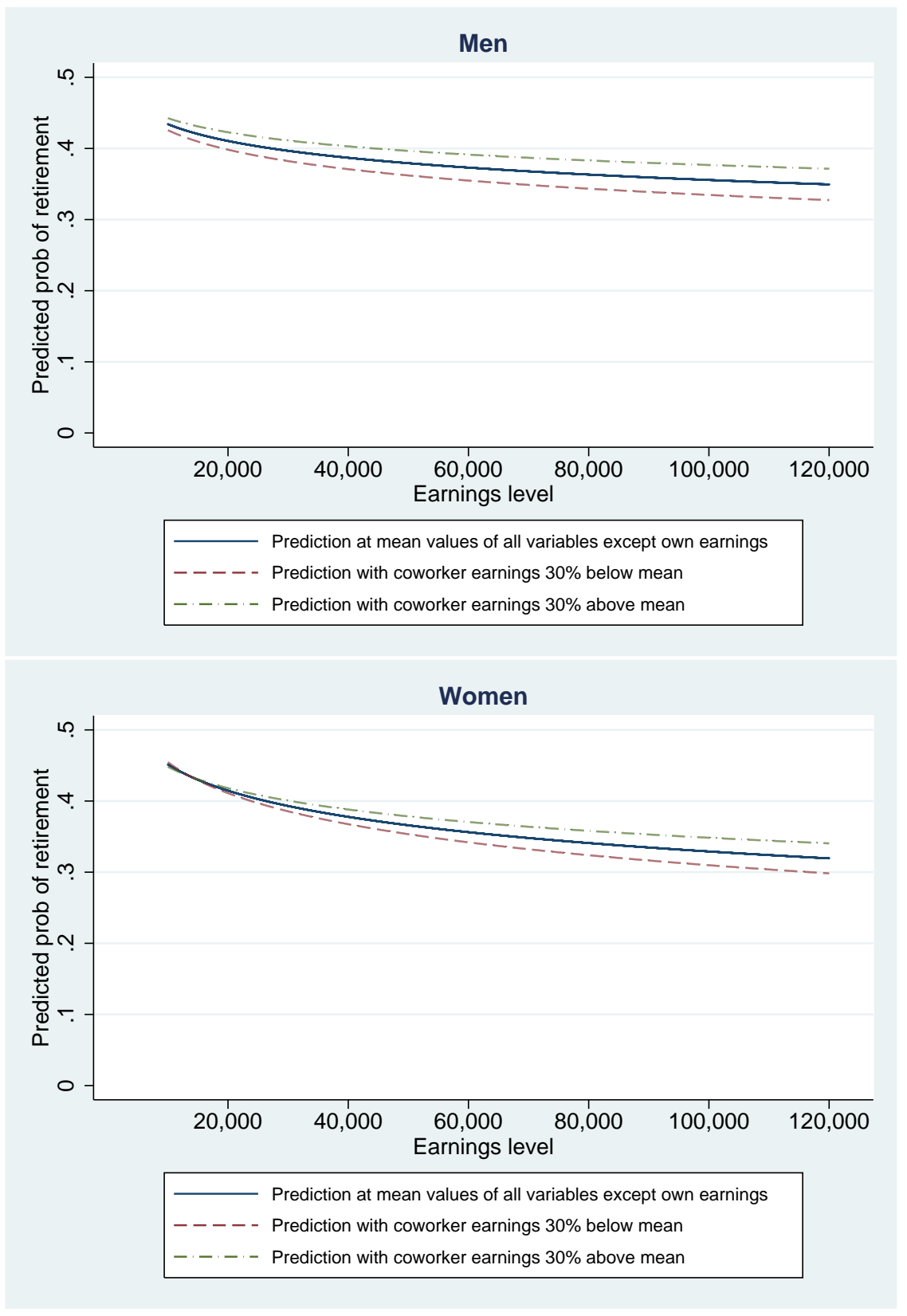

